Article

\title{
Sustainable Development in the Service Industry: Managerial Learning and Management Improvement of Chinese Retailers
}

\author{
Nana Zhang ${ }^{1}$ and Liang Mei ${ }^{2, *}$ (i) \\ 1 School of Economics and Management, Beijing Jiaotong University, Beijing 100044, China; \\ nnzhang@bjtu.edu.cn \\ 2 National School of Development, Peking University, Beijing 100871, China \\ * Correspondence: Liangmei@nsd.pku.edu.cn
}

Received: 10 January 2020; Accepted: 12 February 2020; Published: 14 February 2020

\begin{abstract}
Research in sustainability has focused on the productive industry and other polluting sectors, leaving aside the sustainable development of the service industry such as retail. Increasingly, retail companies are facing substantial sustainability problems such as pressure from resource limitations, fierce competition, the variability of customer needs, and the development of technology. Adopting best practices through managerial learning is the key to achieving sustainable development for retailers. However, there is a lack of discussion of the micro mechanism of sustainable development in the existing sustainable research field. From the perspective of internal sustainable development, taking Chinese retailers as the sample, this study explores the effect of the managerial learning mechanism on sustainable development on the basis of empirical research. First, this study measures the management efficiency of Chinese retailers, which is the micro basis of sustainable development. Second, the effects of two types of managerial learning mechanisms (government-driven and professional organization driven) on management efficiency are tested. The results show that management efficiency contributes to the growth of the total factor productivity in Chinese retailers, and firms should attach importance to the improvement of management efficiency. Specifically, retailers can strengthen management efficiency by establishing managerial learning platforms with professional institutions, and thus prevent the substitution role of absorptive capacity.
\end{abstract}

Keywords: sustainable development; managerial learning; sustainability governance; management efficiency; Chinese retailers

\section{Introduction}

Since 1978, China has developed policies of reform that allowed market forces to transform the economy [1], and various forms of economy emerged, such as the traditional bazaar, state-controlled planned sector, and the more modern firm-type sector [2]. Although market-oriented reforms have boosted China's economy, China is under increasing pressure from economic depression after the rapid economic growth of the last 40 years. Three important ways for China to improve the quality of its economic development and achieve sustainable growth are developing its tertiary industry, changing the traditional factor-driven development model, and raising the total factor productivity [3]. Changing the quality of growth requires changing approaches to development efforts to take account of their combined effects [4]. In 2017, the tertiary industry accounted for 51.6\% of China's GDP. As an important part of the tertiary industry, the service industry is a new engine driving the sustainable development of China's economy, but in recent years, it has also faced the problem of sustainable development. As an example, retailing, which is recognized as the driving force for the supply chain, 
has a huge potential influence on the sustainability performance of national economies [5] but has faced substantial sustainability problems [6] in recent years, such as resource limitations, fierce competition, the variability of customer needs, and the development of technology [7]. The General Office of the State Council of China has issued directives on promoting the innovation and transformation of the physical retail stores, and it is clear that China's retail industry must shift from extensive development to focus on quality and efficiency, reduce circulation costs, improve circulation efficiency, achieve sustainable development, and better meet the new requirements of economic and social development. However, researchers have paid attention to the productive industry and other polluting sectors [8], leaving aside the sustainability scope, practices, and management of other relevant sectors such as retailing or other service industries in the emerging countries' context [9].

Sustainable development refers to the development that meets the needs of the present without compromising the ability of future generations to meet their own needs [4]. The definition emphasizes that companies should reduce their negative impact on future generations [10]. Therefore, companies should adopt the going-concern management model and long-term business model. Although many retailers are aware of the sustainability issues they face, they are stuck in the implementation of sustainable business activities, such as energy conservation and emission reduction. The main reasons run as follows. First, the concept of sustainable development conflicts with the existing development model of enterprises in emerging economies, such as conflicts that arise between low-cost business models which focus on direct stakeholders and corporate social responsibility (CSR) which considers the concerns of less-related stakeholders [10-12]. Second, there is no successful sustainable development reference model. Even the world's leading retailers such as Carrefour and Tesco have not yet worked out a reliable sustainable development model and improved their performance; instead, they adopt a "weak" model of sustainability [13].

Studies have shown that organizational/individual behavioral factors play important roles in sustainable development, such as technical risk, lack of the manager's influence, and top management commitment [14]. Enhancing management practices can improve the ability of manufacturing firms to produce quality products and services while achieving efficient energy saving [15]. Retail research also shows that a number of sustainable development dilemmas that enterprises encounter are managerial factors, such as the lower controllability of operations [10], cultural differences among the top managers [10], and inefficient communication systems, processes and policies established between retailers and suppliers [7]. Some researchers analyze sustainability based on three levels of corporate sustainability management-normative, strategic, and operational [16,17]-with normative management referring to the organizational vision, the strategic one emphasizing the development of sustainability strategy, and the operational one targeting the efficiency of implementation. Particularly, management efficiency mainly depends on the operational level, focusing on the implementation of the sustainability practices among different operational functions [16]. China's retail energy-saving survey shows that strengthening the means and methods of energy-saving management, optimizing the management process and system, improving the supervision, measurement, and audit mechanism of store energy consumption management, and improving the level of energy efficiency management have become the foci of the sustainable development of enterprises in the future [18].

One of the important channels for enterprises to improve productivity and solve the pressure of sustainable development is to improve management efficiency [19-21]. For example, it is necessary to establish a backward product flow management system for the fast movement of food products along the supply chain [8]. The management efficiency of Chinese enterprises is only $70 \%$ of the average level of developed countries such as the United States and the United Kingdom, and even lower than that of developing countries such as Chile, Mexico, and Turkey [22]. It is urgent that Chinese enterprises introduce international best management practices to improve their management efficiency. Since the reform and opening up of China, Wal-Mart, Carrefour, Metro, Tesco, Lotus, Auchan, B\&Q, RT-mart, 7-11, and other excellent foreign retail enterprises have entered China, providing opportunities for Chinese local retail enterprises to learn from them and introduce the best practices of the international 
retail industry (see Table 1). So far, the Chinese retail industry has introduced advanced retail concepts, management models, and practices through managerial learning, which has helped them realize the transformation and upgrading of the retail format [23] (The department store, mom-and-pop stores and other traditional retail formats gradually transformed into shopping centers, hypermarkets, supermarkets and other advanced formats emerging in developed countries.) and make progress in solving the sustainability challenges.

Table 1. Examples of managerial learning of Chinese retailing.

\begin{tabular}{ccc}
\hline Content of Learning & Source of Learning & Adopters \\
\hline Supply chain management & Wal-Mart & Gome Electrical Appliances \\
Stock option incentive & Best Buy & Suning Appliance Group \\
development strategy focused on core business & Wal-Mart & Yonghui Superstores \\
Enterprise resource planning system & SAP & Wu mart \\
\hline
\end{tabular}

Research on managerial learning and absorptive capacity provides explanations for the process of management improvement. Managerial learning is a major approach for enterprises to acquire best practices, which is conducive to the improvement of enterprise management levels and management efficiency $[24,25]$. As executives are the key learning agents navigating the enterprises' development from learning practices [26], managerial learning sources based on their social networks are regarded as main management improvement mechanisms for enterprises [24,25]. Two managerial learning sources have been mainly concerned in prior literature, the government-driven managerial learning source (involving ties with industry associations sponsored by the government [27]) and the professional organization-driven managerial learning source (such as linkages with universities and research institutes [28]). However, only managerial learning sources are not enough, so that enterprises need to further leverage the efficiency of managerial learning sources' transformation, particularly concerning the complexity of inside managerial learning processes influenced by various factors [29]. Among all the factors, absorptive capacity - an ability to recognize, assimilate, and apply new information [30] - is regarded as one of the most important for firms exploiting external knowledge sources to leverage productivity and proficiency [30,31]. The following literature demonstrates a double-edged sword feature of absorptive capacity explaining its role in enterprises' learning process, involving the complementary effect that positively affects the knowledge assimilation and transformation [32], and the substitutional role of external learning knowledge on managerial efficiency [33].

The sustainable study of retail enterprises from the perspective of management promotion will help to analyze enterprises' sustainable development dilemma, and to identify the solution mechanism. However, existing research mainly focuses on the impact of enterprises' sustainable behavior on the external ecological environment and social development, while there is a lack of analysis in the dimensions of enterprises' sustainable practice adoption behavior [17] and sustainable governance mechanism [9]. Therefore, this study takes Chinese retail enterprises as the research sample and adopts the empirical research method to evaluate the management efficiency of Chinese retail enterprises against the background of sustainable development and the influence of different management improvement mechanisms. The conclusion is helpful in answering the following research questions: How do internal micro-management factors affect the sustainable development of an enterprise? How do government-driven and professional organization-driven managerial learning mechanisms affect management efficiency?

Based on the empirical results, this paper further discusses the influence of absorptive capacity on the relationship between managerial learning and management efficiency, providing practical enlightenment for enterprises on "how to implement managerial learning". Our contributions are as follows: 
First, the study enriches the empirical research of the service industry in the field of sustainability. This paper explores the effects of different managerial learning mechanisms on enterprise management efficiency from the micro perspective of internal management improvement.

Second, the study explores the influence of the government-driven managerial learning mechanism and the professional organization-driven managerial learning mechanism on management efficiency, and the results have contributed to the field of managerial learning.

Third, responding to the call by West and Boger [32] that more research is needed on the substitution effects, the results of this study confirm the substitution effect of absorptive capacity on managerial learning, enriching the research on absorptive capacity.

The rest of the paper is structured as follows. The first section states the motivation for this study. Then, a literature review is undertaken of the driving force of sustainable development and sustainability governance. The next part describes the research design, while the fourth section analyzes the findings and presents the results. The study concludes with a discussion on the contributions, limitations, and directions for future research.

\section{Literature Review}

Based on the literature available in the field of retail and managerial learning, we conducted a literature review and constructed theoretical assumptions about enterprises' sustainability governance for leveraging efficiency. Prior literature has concerned the issue from external and internal sustainability perspectives, and more and more retail activities have been affected by the sustainability debate, such as location, size, and the broader future of retail developments [34]. All these discussions indicated the importance of enterprises establishing sustainability governance mechanisms. In recent years, retail enterprises have been facing (i) external sustainability pressures, including ecological and environmental protection [35], laws and institutions, customer requirements, competitive pressure [8], and technical improvement [36]; and (ii) internal sustainability pressures, including human resources management [5,37], cost reduction [38], and operational efficiency improvement [39-41]. Although many retailers are now aware of the importance of responding positively to sustainable development, most leading retailers still run a weak sustainability model [13], making up for losses in natural resources with gains in capital. Most retail enterprises end up straying from sustainability goals, because they encounter several sustainable development dilemmas, such as a lack of a supportive institutional environment [8], lower controllability of operations [10], cultural differences among the top managers [10], and inefficient communication systems, processes and policies established between retailers and suppliers [7].

Institutional mechanism. Based on the external perspective of enterprise development, researchers have shown that the supportive policies and binding policies issued by the government provide an institutional guarantee and constraint for the implementation of the sustainable development of retail enterprises and are important institutional mechanisms for the sustainable development of retail enterprises. First, an important guarantee for retail enterprises to promote sustainable development is to establish an appropriate system [42]. For example, in order to ensure the implementation of a sustainable project, the government has to develop financing and technology support policies $[8,36]$. Second, the binding policy is an indispensable source of pressure for retail enterprises to implement sustainable development actions. The absence of a government policy on the compulsory adoption of sustainable development activities is one of the major barriers identified by retailers [8]. Although the external institutional mechanism plays an important role in guiding retail enterprises to implement sustainable development, the sustainable development behavior of enterprises is regarded as a passive behavior, ignoring the discussion of the following questions: (i) How to solve the internal pressure of sustainable development? (ii) How do internal micro-management factors affect the sustainable development of an enterprise? To answer the above questions, it is urgent to "develop the micro-governance mechanism for the sustainable development of enterprises" [9]. 
Management improvement mechanism. Different from the institutional mechanism that emphasizes the role of external pressure and support, the management improvement mechanism emphasizes that the micro factor (management factor) is the internal basis for retail enterprises to implement sustainable action. Researchers have shown that the role of the management factor on firms' sustainable development is reflected in two ways. First, how retail enterprises affect the sustainable behavior of suppliers and customers depends on their management ability. The implementation of sustainable development activities requires collaboration among stakeholders $[7,13]$, so retailers should have the ability to manage the relationship among stakeholders. Second, management is the key for retail enterprises to cope with internal and external sustainability pressures. To improve the organizational sustainability performance, firms should create an ethical working environment and reduce the turnover tendency, which is related to management practices [37]. Learning and adopting best management practice, ideas, and methods can help firms improve their management cognitive level and human capital, which contribute to the long-term development of enterprises [43,44].

Managerial learning, which is "a process of learning about management and how to manage" [45], is a key management efficiency improvement mechanism. Managerial learning and adopting best management practices generally prevails among retailers, and marginal improvements in management efficiency are evident. Fu et al. [39] studied the British retail industry and found that local retail enterprises could improve their management efficiency by learning the best practices from foreign retail enterprises. Enterprises can adopt formal (such as sino-foreign cooperation, sino-foreign joint venture, license, etc.) and informal (with relatively diverse sources) learning mechanisms to carry out managerial learning [46]. The formal learning mechanism represented by joint ventures and alliances is an important way for latecomer firms to acquire advanced management knowledge; researchers have conducted a rich study on the learning process [47], key influencing factors [29], and so on. Compared to the formal learning mechanism, more research is needed on the informal learning mechanism. Informal learning plays complementaries to the formal learning mechanism on management improvement, as it can provide enterprises with the knowledge that cannot be acquired directly from the formal learning mechanism, such as helping enterprises to master the localized and tacit management knowledge [48] or benefit from "guanxi" of enterprises' executives [26]. As executives are key learning agents in a firm, their managerial learning network plays a key role in the informal learning mechanism [26], which could be mainly divided into two parts: (i) political network, such as establishing ties with the central and local government [27], and (ii) professional network, such as establishing ties with universities and research institutes [28]. Although the networks constructed by executives are considered important informal sources of enterprise managerial learning [49], their effects on firms' development have not been revealed. To fill this research gap, we combined existing research in the field of managerial learning to explore the internal governance mechanism of the sustainable development of retail enterprises- the management improvement mechanism-including the government-driven managerial learning mechanism and professional organization-driven managerial learning mechanism.

Absorptive capacity is "an ability to recognize the value of new information, assimilate it, and apply it to commercial ends" [30: 128], which is important for firms to exploit external knowledge sources [31]. Absorptive capacity is highly related to the expertise of employees (employees with a college education and above) [31]. There are two competing logics for people to understand the role of absorptive capacities on knowledge searching; namely, the complementary logic [32] and the substitutional logic [33]. In the complementary logic, firms with a high absorptive capacity are more likely to get benefits from using external knowledge [50]. Considerable research has studied the role of absorptive capacity as a complement for utilizing external knowledge [32], and these studies mainly focus on the effect of the internal R\&D capability on technology searching in the manufacturing industry [50]. In the substitutional logic, firms with a high absorptive capacity have high levels of confidence in their competencies [33], so they are less likely to be interested in external knowledge [32], and when firms lack a compatible culture, there will be "not invented here" barriers [51]. More research is needed on the substitution effects [32]. 
Based on a review of the literature on retail sustainability, managerial learning, and absorptive capacity, we constructed a research framework to demonstrate the relationships among key variables (see Figure 1).

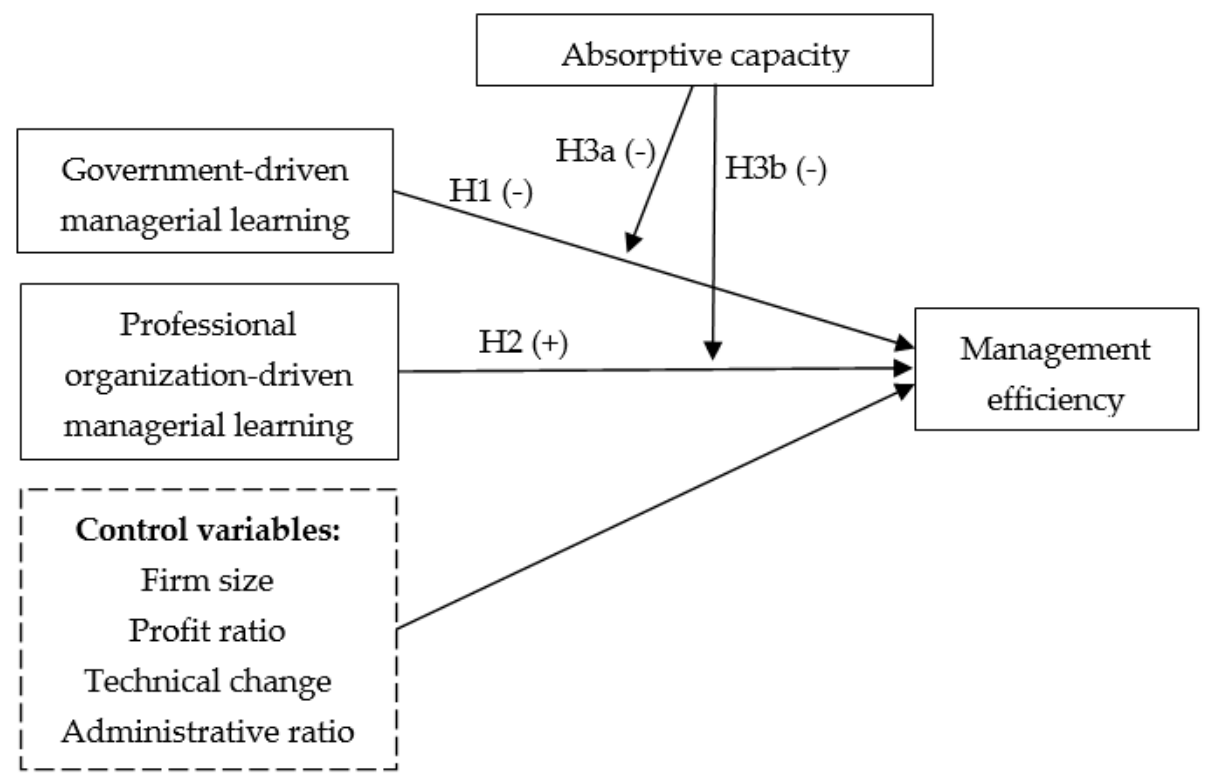

Figure 1. Research framework.

\subsection{The Government-Driven Managerial Learning Mechanism}

Political networking is a very important social capital resource for firms [52]. Due to the defects of the institutional system in the transition economy, the government plays an important complementary role [53]. In order to obtain preferential policies and funds, firms tend to build connections with the government [54,55]. For example, many retailing executives work part-time in industry associations; these are quasi-government institutions that participate in the formulation of the national standards of the industry and in promoting the reform and development of enterprises. In addition, the industry association is a special inter-organizational network, which is a channel for the dissemination and diffusion of knowledge [27]. In the process of the development of Chinese retail enterprises, the industry associations, such as China Chain Franchise Association, China General Chamber of Commerce, and China Commerce Association for General Merchandise, have organized a large number of overseas visits to excellent enterprises, management knowledge training, exhibitions, and other activities, which provide valuable opportunities for enterprises to acquire basic information about best management practices. Thus, political networking is a kind of government-driven learning mechanism for firms.

Researchers raise the potential negative impact caused by political networking. First, maintaining a political network takes up enterprises' resources and causes political burden [56]. The ability to utilize resources will be inhibited when a firm establishes a specific routine to satisfy government expectations [57]. Second, firms' main intentions to establish political networks is to accumulate social capital [54], rather than to acquire new knowledge. Although legitimacy and resources are needed to cope with uncertainty [58], political connection reduces the enthusiasm of enterprises to improve their competitiveness through learning; that is, it promotes the learning inertia of enterprises. Therefore, we believe that the government-driven managerial learning process is not conducive to the improvement of enterprise management efficiency.

H1. Government-driven managerial learning process has a negative impact on the improvement in management efficiency. 


\subsection{Professional Organization-Driven Managerial Learning Mechanism}

Managers' experience in professional organizations represents another important learning network for firms [52]. The executive team plays a role in explaining rules and consulting in the enterprise [59], which is influenced by their network. In reality, business executives usually establish connections with professional organizations, such as universities, research institutes, and consulting institutions, among others. These professional organizations are important platforms for individuals and groups to acquire theoretical knowledge, as well as to exchange, analyze and transform knowledge [60], and they are the "driving forces" behind all the popular management ideas in the market [61]. Therefore, professional knowledge networks constructed by executives are important sources for enterprises to acquire best management practices, and these knowledge networks improve the ability of executives to interpret rules, consult, and help enterprises improve management efficiency. In China, executives of many retail enterprises (such as Jingdong Mall, Alibaba, etc.) usually establish close connections with institutions such as universities; these connections may involve working as off-campus mentors, establishing enterprise research institutes, and holding posts, etc., which strengthen the exploration and application of best retail practices by executives.

H2. Professional organization-driven managerial learning process has a positive impact on the improvement in management efficiency.

Absorptive capacity and government-driven managerial learning mechanism. The industry association in China is a kind of quasi-government, and it masters important industry information and resources, such as the permission to organize learning programs granted by the government (management training, visits to famous international companies, and so on). One of the industry association's duties is to improve the average management level of an industry, but enterprises voluntarily participate in the learning program organized by the industry association. The substitutability of the knowledge and the weak link between the industry association and enterprise highlight the substitutional effect of absorptive capacity. First, the best management practice, encouraged in the learning program organized by the industry association, is an alternative to the management knowledge being accumulated within the organization. The firm with highly educated employees shows a high absorptive capacity [31], and it is much more confident in its internal management knowledge [33], which induces the occurrence of "not invented here" learning barriers [51]. Second, the weak link, characterized by a lack of trustful relationships [62], reduces the trust of a firm in external knowledge [32]. The link between the industry association and enterprise is weak, and there are no monitoring mechanisms for learning processes and feedback mechanisms for learning outcomes, which leads to the increase of the uncertainty of absorbing and applying knowledge for enterprises. Based on the above analysis, the negative effect of government-driven managerial learning is strengthened by absorptive capacity.

H3a. A firm's absorptive capacity strengthens the negative relationship between government-driven managerial learning and management efficiency.

Absorptive capacity and professional organization-driven managerial learning mechanism. Professional organizations, such as higher education institutions and research institutes or consulting companies, are the main sources of professional management knowledge, which is an alternative to the management practices being accumulated within the organization. The substitutability of the resources highlights the substitutional effect of absorptive capacity. First, when the employees are highly educated, the absorptive capacity of the firm is high [31], causing the enterprise to be more confident in its management practices formed by internal accumulation [33], so there is a lack of trust in external knowledge [32]. Second, compared to the internal knowledge, the outcome of learning from external sources is costly and full of uncertainty [63], which will exaggerate the effect of "not invented here" barriers [51] and will reduce the enterprise's learning intent of absorbing external knowledge.

H3b. A firm's absorptive capacity attenuates the positive relationship between professional organization-driven managerial learning and management efficiency. 


\section{Research Design}

\subsection{Evaluation Model}

This study measured the management efficiency of retail enterprises based on the DEA-based Malmquist productivity index. The DEA-based Malmquist productivity index which measures the change in efficiency and change in the frontier technology [64] was constructed by Färe et al. [65]. According to the index, the change of enterprise productivity can be decomposed into three parts: (i) technology progress index, (ii) pure technology efficiency change, and (iii) scale efficiency change. Among them, the change of pure technical efficiency shows the change of enterprise resource allocation ability and management level [66].

First, we established the input-output model to calculate the total factor productivity (TFP) of an enterprise. The operation process of a retail enterprise is essentially an input-output system, and most scholars will focus on indicators related to assets, labor, and costs in the construction of its input-output indicator system $[23,67]$ as the input index, and indicators related to revenue and profits as the output index $[68,69]$. Based on existing research, we constructed the input-output model with four inputs and two outputs (see Figure 2).

Second, we decomposed the value of TFP to get the value of Pure technical efficiency which represents management efficiency. In addition to this, we can get the value of Technical change and Technical efficiency change (being decomposed into Pure technical efficiency and Scale efficiency). All the values are greater than 0 . Additionally, if the values are greater or less than 1 , they indicate an increase or decrease from the previous period to the present, respectively; if the value is equal to 1 , it indicates no change [70].

Third, we further used the Tobit model of panel data to examine the key factors affecting the management efficiency of Chinese retail enterprises. We chose the Tobit model regarding the range of the dependent variable being restricted, and we selected values in a limited interval, in line with Ozbugday et al. [70].

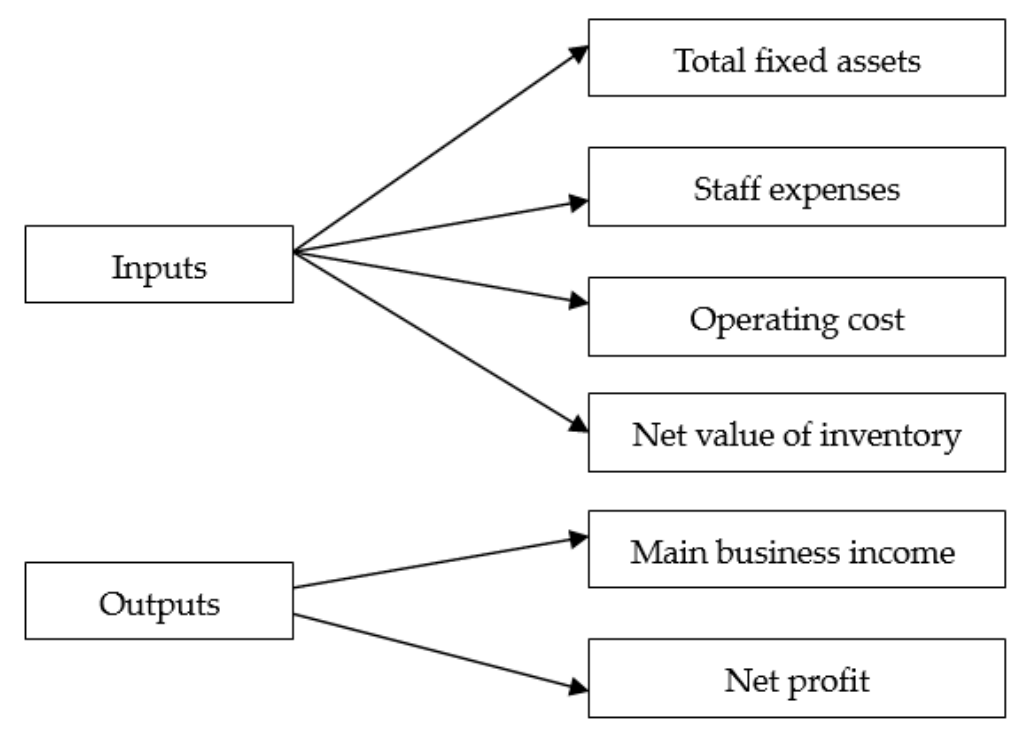

Figure 2. Input-output index system of Chinese retail enterprises.

\subsection{Data and Variables}

The main sources of information are the CSMAR database, the Wind database, and China Infobank, which provide annual reports and financial information on Chinese listed retail companies. Given the volatility of economic data around 2007 because of the world financial crisis [71], and in order to ensure the coherence of the research sample data, we selected data of listed Chinese retail companies from 
2007 to 2014 for analysis. There are 88 listed companies in the retail industry according to the industry classification system of the CSRC. After deleting the incomplete and unusable samples, we obtained the panel data of 51 listed retail companies from 2007 to 2014 to measure the Malmquist productivity index. The descriptive statistics of input and output variables can be seen in Table 2.

Table 2. The descriptive statistics of the input and output variables from 2007 to $2014(\mathrm{~N}=408)$.

\begin{tabular}{ccccc}
\hline Variable Name & Mean & S.D. & Min & Max \\
\hline Main business income & 827,000 & $1,530,000$ & 18,000 & $10,900,000$ \\
Net profit & 27,200 & 51,900 & 61.13 & 489,000 \\
Operating cost & 790,000 & $1,480,000$ & 18,900 & $11,000,000$ \\
Net Value of Inventory & 116,000 & 224,000 & 178.50 & $1,830,000$ \\
Total fixed assets & 128,000 & 201,000 & 3900 & $1,260,000$ \\
Staff expenses & 6110 & 11,300 & 6.21 & 61,400 \\
\hline
\end{tabular}

Unit: Ten Thousand Yuan.

In the empirical test, we obtained the panel data of 48 listed retail companies from 2007 to 2014 after deleting the incomplete and unusable samples. The executive information comes from the research database of Chinese listed companies' governance structure and China Infobank. All the financial data involved are from the annual reports of Chinese listed companies, and some basic information from the company comes from the CSMAR database. In addition, the data of the explained variables are derived from the calculation of the decomposition value of the total factor productivity. Constructs and measurements are illustrated in Table 3.

Table 3. Constructs and Measurements.

\begin{tabular}{|c|c|c|c|}
\hline Constructs & Definition & Measurement Items & References \\
\hline \multicolumn{4}{|c|}{ Dependent Variable } \\
\hline $\begin{array}{l}\text { Management } \\
\text { efficiency (ME) }\end{array}$ & $\begin{array}{l}\text { Enterprise resource } \\
\text { allocation level }\end{array}$ & $\begin{array}{l}\text { The change value of pure technical } \\
\text { efficiency in the decomposition value of } \\
\text { enterprise total factor productivity. }\end{array}$ & $\begin{array}{c}\text { Shan [72]; } \\
\text { Jiang et al. [23] }\end{array}$ \\
\hline \multicolumn{4}{|c|}{ Independent Variable } \\
\hline $\begin{array}{l}\text { Government-driven } \\
\text { managerial learning } \\
\text { (GML) }\end{array}$ & $\begin{array}{l}\text { Learning channels from } \\
\text { government agencies }\end{array}$ & $\begin{array}{l}\text { Measure whether executives work } \\
\text { part-time in industry associations. The } \\
\text { index is assigned } 1 \text { if the company's } \\
\text { senior executive is or has been working } \\
\text { or working part-time in an industry } \\
\text { association. Otherwise, it is } 0 .\end{array}$ & $\mathrm{Li}[27]$ \\
\hline $\begin{array}{l}\text { Professional } \\
\text { organization-driven } \\
\text { managerial learning } \\
\text { (PML) }\end{array}$ & $\begin{array}{l}\text { Learning channels from } \\
\text { professional } \\
\text { management knowledge } \\
\text { platform }\end{array}$ & $\begin{array}{l}\text { Collate statistics on executives' } \\
\text { part-time jobs in 1.higher education } \\
\text { institutions and research institutes or } \\
\text { 2.consulting and training institutions. } \\
\text { The index is assigned } 1 \text { if executives } \\
\text { construct one type of management } \\
\text { knowledge connection; } 2 \text { if they } \\
\text { construct two types. Otherwise, it is } 0 .\end{array}$ & - \\
\hline \multicolumn{4}{|c|}{ Moderator } \\
\hline $\begin{array}{l}\text { Absorptive } \\
\text { capacity(AC) }\end{array}$ & $\begin{array}{l}\text { The ability to recognize, } \\
\text { assimilate and apply new } \\
\text { information }\end{array}$ & $\begin{array}{c}\text { The proportion of employees with } \\
\text { education level above Bachelor's } \\
\text { degree. }\end{array}$ & $\begin{array}{l}\text { Minbaeva et al. } \\
\text { [73]; Liao [74] }\end{array}$ \\
\hline
\end{tabular}


Table 3. Cont

\begin{tabular}{|c|c|c|c|}
\hline Constructs & Definition & Measurement Items & References \\
\hline \multicolumn{4}{|c|}{ Control Variable } \\
\hline Firm size(LNS) & -- & $\begin{array}{l}\text { The logarithm of the number of } \\
\text { employees. }\end{array}$ & $\begin{array}{l}\text { Vomberg et al. [75]; } \\
\text { Uotila et al. [76] }\end{array}$ \\
\hline Profit ratio(PR) & -- & $\begin{array}{l}\text { The ratio of operating profit to } \\
\text { operating income. }\end{array}$ & -- \\
\hline $\begin{array}{l}\text { Technical change } \\
\text { index(TC) }\end{array}$ & $\begin{array}{l}\text { Productivity gains from } \\
\text { technological advances }\end{array}$ & $\begin{array}{l}\text { Technical change index in the } \\
\text { decomposition value of total factor } \\
\text { productivity. }\end{array}$ & Jiang et al. [23] \\
\hline $\begin{array}{l}\text { Administrative } \\
\text { ratio(AR) }\end{array}$ & -- & $\begin{array}{l}\text { The proportion of administrative staff in } \\
\text { the total number of employees. }\end{array}$ & -- \\
\hline $\begin{array}{l}\text { Foreign direct } \\
\text { investment (FDI) }\end{array}$ & $\begin{array}{l}\text { Foreign direct } \\
\text { investment }\end{array}$ & $\begin{array}{c}\text { The proportion of foreign investment in } \\
\text { the region. }\end{array}$ & Yao and Zhang [66] \\
\hline
\end{tabular}

\section{Empirical Results}

\subsection{Evaluation of Management Efficiency of Chinese Retail Firms}

Based on the input-oriented DEA model setting with constant return to scale, this study calculates the annual Malmquist productivity index and its decomposition value from 49 listed companies in China's retail industry from 2007 to 2014 with DEAP2.1 software (see Table 4).

Table 4. The total factor productivity index and decomposition value of listed companies in China's retail industry (2007-2014).

\begin{tabular}{cccccc}
\hline Year & $\begin{array}{c}\text { Technical } \\
\text { Efficiency } \\
\text { Change (Effch) }\end{array}$ & $\begin{array}{c}\text { Technical } \\
\text { Change } \\
\text { (Techch) }\end{array}$ & $\begin{array}{c}\text { Pure Technical } \\
\text { Efficiency } \\
\text { (Pech) }\end{array}$ & $\begin{array}{c}\text { Scale } \\
\text { Efficiency } \\
\text { (Sech) }\end{array}$ & $\begin{array}{c}\text { Total Factor } \\
\text { Productivity } \\
\text { (Tfpch) }\end{array}$ \\
\hline $2007-2008$ & 0.982 & 1.038 & 0.989 & 0.992 & 1.019 \\
$2008-2009$ & 1.01 & 1.064 & 1.002 & 1.008 & 1.075 \\
$2009-2010$ & 0.98 & 1.009 & 0.985 & 0.995 & 0.989 \\
$2010-2011$ & 1.031 & 0.985 & 1.022 & 1.008 & 1.016 \\
$2011-2012$ & 0.994 & 0.995 & 1 & 0.993 & 0.989 \\
$2012-2013$ & 1.011 & 1.014 & 1.007 & 1.004 & 1.025 \\
$2013-2014$ & 0.986 & 0.997 & 1 & 0.986 & 0.983 \\
Mean & 0.999 & 1.014 & 1.001 & 0.998 & 1.013 \\
\hline
\end{tabular}

From the overall average level, the total factor productivity of listed companies in China's retail industry showed an upward trend from 2007 to 2014, with a total factor productivity index of 1.013 , achieving an increase of $1.3 \%$. The results show that the total factor productivity index of listed companies in China's retail industry is generally optimistic, and its growth is mainly due to technological progress (an increase of 1.4\%) and improved management efficiency (an increase of $0.1 \%$ ). At the same time, the technical efficiency decreased relatively at a rate of $0.1 \%$.

From the point of view of technological change, the growth rate of technical change among listed companies in China's retail sector is generally higher, reaching $6.4 \%$ in 2009. But the pace of technological change has slowed sharply since 2011. This is due to the fact that the development of China's business to business (B2B) and business to customer (B2C) models has had a significant impact on traditional retail enterprises, and the traditional retail enterprises have been under pressure to introduce e-commerce-related technology (this study mainly focuses on traditional retail enterprises). However, technological progress is still the main factor for the total factor productivity growth of listed companies, which also reflects that the introduction of advanced foreign retail technology, equipment, and tools improves the overall productivity of China's retail industry. 
In terms of technological efficiency changes, there have been increases in 2009,2011, and 2013, with the fastest growth rate reaching $3.1 \%$ in 2011. In general, the technical efficiency of listed companies in China's retail industry shows a wavy trend, and the change in scale efficiency is the main reason for this. The reason for the change of scale efficiency in a wavy trend is that China's economy has gradually entered a new normal period with a slower growth since 2011. Being negatively affected by the economic slowdown, the scale expansion rate of the retail industry has been greatly reduced, and most enterprises began to transform their development model from scale expansion to quality improvement. The increasing trend of pure technical efficiency indicates that the improvement of the management level is an important source of productivity growth for Chinese retail enterprises. As Chinese retail enterprises enter into a transformation period, they gradually focus on the transformation and upgrading of the development mode, management mode, and organizational mode.

Based on the above analysis, the main sources of productivity growth in China's retail sector are technical change and pure technical efficiency (improved management efficiency). Furthermore, the improvement of management efficiency shows that Chinese retail enterprises have begun to enter the stage of sustainable development.

\subsection{Hypothesis Testing and Results}

Table 5 summarizes the descriptive statistics and correlations of constructs. In addition, this study analyzes the antecedents of management efficiency improvement through the Tobit model. Table 6 summarizes the main results for Hypotheses 1 to 4 . Model 1 is the baseline model involving the full set of controls. As for the control variables, Model 1 shows that Firm size, Profit ratio, and Administrative ratio have positive and significant correlations with Management efficiency; Model 2 complements the two main independent variables (Government-driven managerial learning and Professional organization-driven managerial learning) to the baseline model. This shows the significant negative effect of Government-driven managerial learning on Management efficiency (coefficient $=-0.008$ at the level $p<0.1$ ), and the significant positive relationship between Professional organization-driven managerial learning and Management efficiency (coefficient $=0.008$ at the level $p<0.05$ ), which supports Hypothesis 1 and Hypothesis 2. This result indicates that government organizations such as industry associations are not positive sources of enterprise management efficiency improvement while, in contrast, professional management knowledge institutions such as universities, research institutes, and consulting companies are important sources of enterprise managerial learning, which do matter in the leverage of management efficiency improvement.

Hypothesis 3a refers to the positive moderating effect of Absorptive capacity on the relationship between Government-driven managerial learning and Management efficiency. The result of Model 4 does not support Hypothesis $3 a$, as the coefficient of the interaction term on Management efficiency ( $\beta=0.024)$ is not significant and it is positive. In addition, Hypothesis $3 \mathrm{~b}$ is supported as the negative significant effect of the interaction term on Management efficiency ( $\beta=-0.038$ at the level $p<0.05$ ).

Table 5. Descriptive statistics and correlation matrix of variables.

\begin{tabular}{|c|c|c|c|c|c|c|c|c|c|c|c|c|}
\hline & $\mathbf{N}$ & Mean & S.D. & 1 & 2 & 3 & 4 & 5 & 6 & 7 & 8 & 9 \\
\hline 2.GML & 294 & 0.241 & 0.429 & -0.074 & 1 & & & & & & & \\
\hline 4.AC & 294 & 0.190 & 0.193 & 0.068 & $0.093 *$ & -0.031 & 1 & & & & & \\
\hline 5.LNS & 294 & 7.744 & 1.193 & 0.024 & 0.028 & -.0038 & $-0.112 *$ & 1 & & & & \\
\hline 6.PR & 294 & 0.053 & 0.035 & $0.211^{* * *}$ & -0.061 & 0.047 & -0.010 * & $-0.274^{* * *}$ & 1 & & & \\
\hline 9.FDI & 294 & 0.069 & 0.065 & 0.012 & $0.113^{*}$ & $0.136^{* * *}$ & -0.055 & 0.043 & 0.054 & -0.006 & 0.028 & 1 \\
\hline
\end{tabular}

*** Significant at $0.01 ;{ }^{* *}$ significant at $0.05 ;{ }^{*}$ significant at 0.1 . 
Table 6. Empirical results (dependent variable $=\mathrm{ME}$ ).

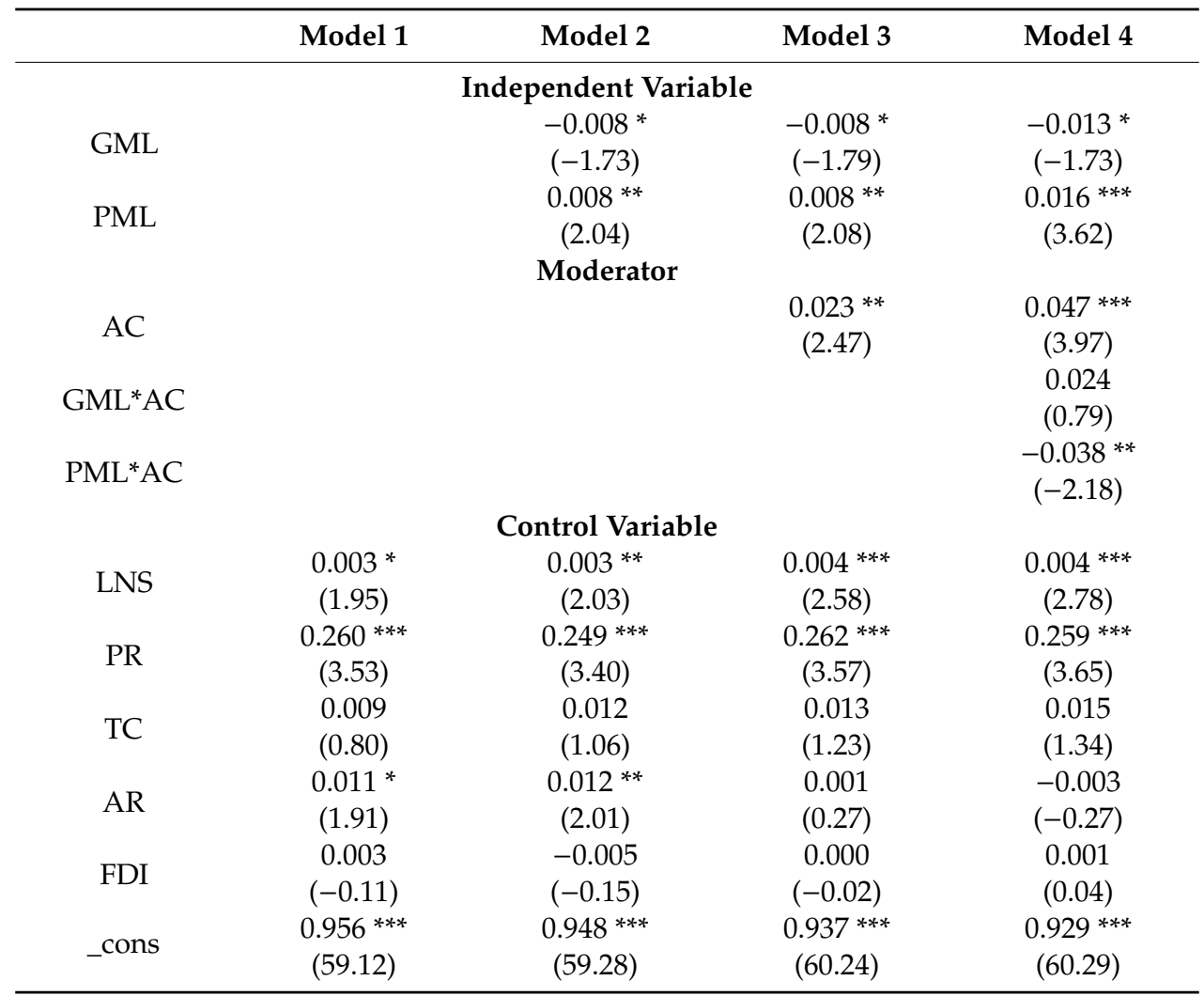

${ }^{* * *}$ Significant at $0.01 ;{ }^{* *}$ significant at $0.05 ;{ }^{*}$ significant at 0.1 .

\section{Discussion and Conclusions}

The total factor productivity of listed companies in the Chinese retail sector is on the rise, with an overall growth rate of $1.3 \%$. In the decomposition of the total factor productivity, the scale efficiency fluctuates under the influence of the overall scale shrinkage of the retail industry. The pure technical efficiency shows a general upward trend under the enterprise's connotational development strategy, which indicates that the improvement of management efficiency is one of the important sources for the development of Chinese retail enterprises, and which shows that the management basis for the sustainable development of China's retail enterprises is improving.

The empirical test results show that most hypotheses proposed in the study (except for Hypothesis 3a) have been verified, and the empirical results are consistent with the theoretical deduction. First, the government-driven managerial learning mechanism has shown a negative impact on the management efficiency. Possible reasons for this include: (i) Although the government helps reduce the information asymmetry in managerial learning, it mainly helps enterprises to build communication with the outside world, without directly affecting the improvement of the enterprise management level. (ii) The lack of supervision on the learning process and learning results makes it difficult for enterprises to ensure the learning effect. (iii) Most enterprises do not form a strong learning intention when they adopt government-driven managerial learning, because they only regard it as a way to accumulate political resources.

Second, the professional organization-driven managerial learning mechanism has shown a positive impact on the management efficiency, which proved that establishing networking with a professional organization is helpful for the firm to acquire best practice. Professional knowledge organizations are important sources for enterprises to acquire best management practices, and they can help enterprises acquire management knowledge and improve the management level. 
Third, the study takes the absorptive capacity-represented by the education level of employees-as the moderator; it negatively moderates the relationship between the professional organization-driven managerial learning and the management efficiency. The result proved the substitution effect of absorption capacity, meaning that when the employees of an enterprise have a higher level of education, the enterprise is more confident in its own management practice, rather than making efforts to engage in external learning from professional institutions. In addition, under the influence of organizational inertia, the managerial learning motivation of the firm is reduced, which in turn reduces the learning efficiency.

\subsection{The Implications for Theory and Practice}

This paper makes three main academic contributions. The first is to the sustainability literature. Responding to "Retailers play an important role in promoting sustainability" proposed by Sinha [41] and "Research on sustainable development in services is needed" proposed by Delai and Takahashi [9], the study takes Chinese retail enterprises as the research object and identifies the contribution of management efficiency to the sustainable development of firms based on measuring the total factor productivity. The results enrich the empirical research of the service industry in the field of sustainability. In addition, this paper explores the effects of different managerial learning mechanisms on enterprise management efficiency from the micro perspective of internal management improvement, responding to "Develop the micro-governance mechanism for the sustainable development of enterprises" proposed by Delai and Takahashi [9].

The second contribution is to the managerial learning literature. Responding to "Managerial learning contributes to the long-term development of enterprises" proposed by Chen et al. [43] and Yuan and Chen [44], the study explores the influence of the government-driven managerial learning mechanism and the professional organization-driven managerial learning mechanism on management efficiency, and the defects and deficiencies of the government-driven managerial learning mechanism in the context of China's transitional economy. The results have contributed to the field of managerial learning.

The third contribution is to the absorptive capacity literature. Prior literature has mostly demonstrated the complementary effect of absorptive capacity on managerial learning sources, which encourages enterprises to leverage their absorptive capacity when promoting managerial learning activities to improve managerial efficiency [31,32]. We argue that absorptive capacity plays a role in constraining the organizational learning effect for managerial efficiency as well, responding to "more research is needed on substitution effects of absorptive capacity" proposed by West and Bogers [32]. Since the results of this study confirmed the substitution effect of absorptive capacity on managerial learning, we complement a double-edged sword view of absorptive capacity from substitution logic, enriching the relevant absorptive capacity literature with contingency considerations [33].

This paper has three main practical implications. First, retail enterprises should attach importance to learning and introducing best management practices while responding to customer needs and changing business models. The results of this paper show that the contribution of management efficiency to the total factor productivity of retail enterprises is increasing, and management efficiency is an important guarantee for the sustainable development of enterprises.

Second, professional organization-driven managerial learning contributes to the improvement of management efficiency, so retail enterprises should give full play to the positive role of professional institutions in the managerial learning process. At the same time, in the context of China's transitional economy, although the government plays an important role in promoting overall social and economic progress, companies participate in government-driven managerial learning as a way to accumulate political capital rather than as a source of advanced management practices. Therefore, the government should strengthen the supervision of the enterprise learning process and the learning results by establishing a scientific supervision method. 
Third, enterprises can effectively acquire management knowledge by establishing a network with professional institutions. However, enterprises should prevent the substitution of absorptive capacity and avoid companies resisting managerial learning because of overconfidence and organizational inertia.

\subsection{Limitations}

This paper has two main limitations. First, the study relates to only one country and one industry, and further comparative studies are needed. Second, for the professional institutions, we do not have a hierarchy of professional institutions, and we do not distinguish between the frequencies with which companies interact with professional institutions. Further research should pay much more attention to the classification of professional institutions.

Author Contributions: The authors' contributions are as follows: conceptualization, N.Z.; methodology, N.Z.; formal analysis, L.M.; writing—original draft preparation, N.Z.; writing—review and editing, N.Z. and L.M. All authors have read and agreed to the published version of the manuscript.

Funding: This research was funded by Natural Science Foundation of Beijing, China (Grant Number 9204030), National Natural Science Youth Foundation of China (Grant Number 71704090), China National Postdoctoral Science Foundation (Grant Number 2017M610097), China National Postdoctoral Specific Science Foundation (Grant Number 2018T110110).

Conflicts of Interest: The authors declare no conflict of interest.

\section{References}

1. Dana, L.P. Small business as a supplement in the People's Republic of China (PRC). J. Small Bus. Manag. 1999, 37, 76-80.

2. Dana, L.P. Asian Models of Entrepreneurship-From the Indian Union and Nepal to the Japanese Archipelago: Context, Policy and Practice, 2nd ed.; Word Scientific: London, UK, 2014; pp. 1-17.

3. Cheng, H.; Wang, M.; Li, T. The effects of management practices on total factor productivity: New evidence based on Chinese employer-employee survey (CEES). S. China. J. Econ. 2018, 37, 123-140.

4. United Nations. Available online: https://www.un.org/ga/search/view_doc.asp?symbol=A/42/427\&Lang=E (accessed on 13 February 2020).

5. Erol, I.; Cakar, N.; Erel, D.; Sari, R. Sustainability in the Turkish retailing industry. Sustain. Dev. 2009, 17, 49-67. [CrossRef]

6. Jørgensen, S.; Pedersen, L.J.T. Toward smart and sustainable business models in retail. In Innovation for Sustainability; Springer Science and Business Media LLC: London, UK, 2019; Volume 10, pp. 177-192.

7. Claro, D.P.; Neto, S.A.L.; Claro, P.B.D.O. Sustainability drivers in food retail. J. Retail. Consum. Serv. 2013, 20, 365-371. [CrossRef]

8. Vijayan, G.; Kamarulzaman, N.H.; Mohamed, Z.A.; Abdullah, A.M. Sustainability in food retail industry through reverse logistics. Int. J. Supply Chain Manag. 2014, 3, 11-23.

9. Delai, I.; Takahashi, S. Corporate sustainability in emerging markets: insights from the practices reported by the Brazilian retailers. J. Clean. Prod. 2013, 47, 211-221. [CrossRef]

10. Lueg, R.; Pedersen, M.M.; Clemmensen, S.N. The role of corporate sustainability in a low-cost business model-A case study in the Scandinavian fashion industry. Bus. Strateg. Environ. 2015, 24, 344-359. [CrossRef]

11. Beckmann, M.; Hielscher, S.; Pies, I. Commitment strategies for sustainability: how business firms can transform trade-offs into win-win outcomes. Bus. Strateg. Environ. 2014, 23, 18-37. [CrossRef]

12. Hahn, T.; Figge, F.; Pinkse, J.; Preuss, L. Trade-offs in corporate sustainability: you can't have your cake and eat it. Bus. Strat. Environ. 2010, 19, 217-229. [CrossRef]

13. Jones, P.; Comfort, D.; Hillier, D. Sustainability in the global shop window. Int. J. Retail. Distrib. Manag. 2011, 39, 256-271. [CrossRef]

14. Lee, K.H. Drivers and barriers to energy efficiency management for sustainable development. Sustain. Dev. 2015, 23, 16-25. [CrossRef]

15. Fernando, Y.; Hor, W.L. Impacts of energy management practices on energy efficiency and carbon emissions reduction: A survey of malaysian manufacturing firms. Resour. Conserv. Recycl. 2017, 126, 62-73. [CrossRef] 
16. Baumgartner, R.J. Managing corporate sustainability and CSR: A conceptual framework combining values, strategies and instruments contributing to sustainable development. Corp. Soc. Responsib. Environ. Manag. 2014, 21, 258-271. [CrossRef]

17. Simões, C.; Sebastiani, R. The nature of the relationship between corporate identity and corporate sustainability: evidence from the retail industry. Bus. Ethic-Q. 2017, 27, 423-453. [CrossRef]

18. Ministry of commerce of the people's republic of China. Available online: http://ltfzs.mofcom.gov.cn/article/ ztzzn/hzzn/201711/20171102667434.shtml (accessed on 13 February 2020).

19. Syverson, C. What determines productivity? J. Econ. Lit. 2011, 49, 326-365. [CrossRef]

20. Bloom, N.; Lemos, R.; Sadun, R.; Van Reenen, J. Does management matter in schools? Econ. J. 2015, 125, 647-674. [CrossRef]

21. Shah, A.A.; Wu, D.; Korotkov, V. Are sustainable banks efficient and productive? A data envelopment analysis and the malmquist productivity index analysis. Sustainability 2019, 11, 2398. [CrossRef]

22. Bloom, N.; Brynjolfsson, E.; Foster, L.; Jarmin, R.; Patnaik, M.; Saporta-Eksten, I.; Van Reenen, J. What drives Differences in management? What Drives Differ. Manag. 2017.

23. Jiang, X.Y.; Ren, P.Y.; Li, Y.Y. Research on business efficiency of China retail chain enterprise based on data envelopment analysis. Oper. Res. Manag. Sci. 2011, 20, 185-192. (In Chinese)

24. Chen, P.-L.; Tan, D.; Jean, R.-J. “Bryan” Foreign knowledge acquisition through inter-firm collaboration and recruitment: implications for domestic growth of emerging market firms. Int. Bus. Rev. 2016, 25, 221-232. [CrossRef]

25. Fu, X. Foreign direct investment and managerial knowledge spillovers through the diffusion of management practices. J. Manag. Stud. 2012, 49, 970-999. [CrossRef]

26. Dubey, R.; Gunasekaran, A.; Childe, S.J.; Papadopoulos, T.; Hazen, B.T.; Roubaud, D. Examining top management commitment to TQM diffusion using institutional and upper echelon theories. Int. J. Prod. Res. 2017, 56, 2988-3006. [CrossRef]

27. Li, J.Y. An Empirical Research on Business Association Network Features, Knowledge Absorption Pattern and Enterprises Innovation Performance. Ph.D. Thesis, Southwestern University of finance and Economics, Chengdu, China, September 2013.

28. Higgins, M.C.; Gulati, R. Getting off to a good start: The effects of upper echelon affiliations on underwriter prestige. Organ. Sci. 2003, 14, 244-263. [CrossRef]

29. Tsang, E.W.K. Managerial learning in foreign-invested enterprises of China. Manag. Int. Rev. 2001, 41, $29-51$.

30. Cohen, W.M.; Levinthal, D.A. Absorptive capacity: A new perspective on learning and innovation. Adm. Sci. Q. 1990, 35, 128. [CrossRef]

31. Grimpe, C.; Sofka, W. Search patterns and absorptive capacity: Low-and high-technology sectors in European countries. Res. Policy 2009, 38, 495-506. [CrossRef]

32. West, J.; Bogers, M. Leveraging external sources of innovation: A review of research on open innovation. J. Prod. Innov. Manag. 2014, 31, 814-831. [CrossRef]

33. Mei, L.; Zhang, T.; Chen, J. Exploring the effects of inter-firm linkages on SMEs' open innovation from an ecosystem perspective: An empirical study of Chinese manufacturing SMEs. Technol. Forecast. Soc. Chang. 2019, 144, 118-128. [CrossRef]

34. Yrjänä, L.; Rashidfarokhi, A.; Toivonen, S.; Viitanen, K. Looking at retail planning policy through a sustainability lens: Evidence from policy discourse in Finland. Land Use Policy 2018, 79, 190-198. [CrossRef]

35. Bilińska-Reformat, K.; Kucharska, B.; Twardzik, M.; Dolega, L. Sustainable development concept and creation of innovative business models by retail chains. Int. J. Retail. Distrib. Manag. 2019, 47, 2-18. [CrossRef]

36. Li, Y.; Sha, R. The evaluation of energy conservation development and sustainability of the retail industry in China. Energy Sources Part B 2014, 9, 207-213. [CrossRef]

37. Lee, S.H.; Ha-Brookshire, J. Ethical climate and job attitude in fashion retail employees' turnover intention, and perceived organizational sustainability performance: A cross-sectional study. Sustainability 2017, 9, 465. [CrossRef]

38. Naidoo, M.; Gasparatos, A. Corporate environmental sustainability in the retail sector: Drivers, strategies and performance measurement. J. Clean. Prod. 2018, 203, 125-142. [CrossRef]

39. Fu, X.; Helmers, C.; Zhang, J. The two faces of foreign management capabilities: FDI and productive efficiency in the UK retail sector. Int. Bus. Rev. 2012, 21, 71-88. [CrossRef] 
40. Wathne, K.H.; Biong, H.; Heide, J.B. Choice of supplier in embedded markets: Relationship and marketing program Effects. J. Mark. 2001, 65, 54-66. [CrossRef]

41. Sinha, R. Green retailing: An exploratory study examining the effects of sustainability on global retail landscape. In Proceedings of the Conference on Inclusive \& Sustainable Growth Role of Industry, Government and Society, Nagpur, India, 7 July 2011.

42. Lovre, K.; Brankov, T.; Koviljko, L.; Tatjana, B. Multiple sustainability dimensions of retail sector in Serbia until 2013. Industrija 2016, 44, 133-149. [CrossRef]

43. Bao, Y.; Chen, X.; Zhou, K.Z. External learning, market dynamics, and radical innovation: Evidence from China's high-tech firms. J. Bus. Res. 2012, 65, 1226-1233. [CrossRef]

44. Yuan, L.; Chen, X. Managerial learning and new product innovativeness in high-tech industries: Curvilinear effect and the role of multilevel institutional support. Ind. Mark. Manag. 2015, 50, 51-59. [CrossRef]

45. Simon, L.; Davies, G. A contextual approach to management learning: The hungarian case. Organ. Stud. 1996, 17, 269-289. [CrossRef]

46. Xie, W. Definition, characteristics and influential factors of managerial learning. Sci. Sci. Manag. SET 2008, 29, 179-183. (In Chinese)

47. Lin, X. Local partner acquisition of managerial knowledge in international joint ventures: Focusing on foreign management control. Manag. Int. Rev. 2005, 45, 219-237.

48. Deakins, D.; Battisti, M.; Coetzer, A.; Roxas, H. Predicting management development and learning behavior in New Zealand SMEs. Int. J. Entrepreneurship Innov. 2012, 13, 11-24. [CrossRef]

49. Perez, V.F.; Gutierrez-Gutierrez, L. External managerial networks, strategic flexibility and organisational learning: A comparative study among non-QM, ISO and TQM firms. Total. Qual. Manag. Bus. Excel. 2013, 24, 243-258. [CrossRef]

50. Fabrizio, K.R. Absorptive capacity and the search for innovation. Res. Policy 2009, 38, 255-267. [CrossRef]

51. Chesbrough, H.W. Open Innovation: The New Imperative for Creating and Profiting from Technology; Harvard Business Press: Boston, MA, USA, 2003.

52. Jiang, X.; Liu, H.; Fey, C.; Jiang, F. Entrepreneurial orientation, network resource acquisition, and firm performance: A network approach. J. Bus. Res. 2018, 87, 46-57. [CrossRef]

53. Lester, R.H.; Hillman, A.; Zardkoohi, A.; Cannella, A.A. Former government officials as outside directors: The role of human and social capital. Acad. Manag. J. 2008, 51, 999-1013. [CrossRef]

54. Luu, N.; Ngo, L.V. Entrepreneurial orientation and social ties in transitional economies. Long Range Plan. 2019, 52, 103-116. [CrossRef]

55. Liu, Q.; Tang, J.; Tian, G.G. Does political capital create value in the IPO market? Evidence from China. J. Corp. Finance 2013, 23, 395-413. [CrossRef]

56. Tang, S.; Sun, Z. The political connections, the CEO' s salary, and firm's future management performances. Manag. World 2014, 5, 93-188. (In Chinese)

57. Li, J.; Xia, J.; Zajac, E.J. On the duality of political and economic stakeholder influence on firm innovation performance: Theory and evidence from Chinese firms. Strateg. Manag. J. 2018, 39, 193-216. [CrossRef]

58. Acquaah, M. Social networking relationships, firm-specific managerial experience and firm performance in a transition economy: A comparative analysis of family owned and nonfamily firms. Strateg. Manag. J. 2012, 33, 1215-1228. [CrossRef]

59. Masulis, R.W.; Wang, C.; Xie, F. Globalizing the boardroom-The effects of foreign directors on corporate governance and firm performance. J. Account. Econ. 2012, 53, 527-554. [CrossRef]

60. Soulsby, A.; Clark, E. The emergence of post-communist management in the Czech Republic. Organ. Stud. 1996, 17, 227-247. [CrossRef]

61. Abrahamson, E. Management fashion. Acad. Manag. Rev. 1996, 21, 254-285. [CrossRef]

62. Wu, J.; Wang, X.; Guo, B. Co-evolution of exploration-exploitation strategy and weak-strong ties portfolios: A longitudinal case study. Eur. Manag. Rev. 2019, 16, 1043-1973. [CrossRef]

63. Liu, Y.; Maula, M. Local partnering in foreign ventures: Uncertainty, experiential learning, and syndication in cross-border venture capital investments. Acad. Manag. J. 2016, 59, 1407-1429. [CrossRef]

64. Wu, J.; Zhu, Q.; Yin, P.; Song, M. Measuring energy and environmental performance for regions in China by using DEA-based Malmquist indices. Oper. Res. 2017, 17, 715-735. [CrossRef]

65. Färe, R.; Grosskopf, S.; Lindgren, B.; Roos, P. Productivity changes in Swedish pharamacies 1980-1989: A non-parametric malmquist approach. Int. Appl. Product. Effic. Anal. 1992, 3, 81-97. 
66. Yao, Y.; Zhang, Q. An analysis of technological efficiency of Chinese industrial firm. Econ. Res. J. 2001, 10, 13-19. (In Chinese)

67. Barros, C.P. Efficiency measurement among hypermarkets and supermarkets and the identification of the efficiency drivers: A case study. Int. J. Retail. Distrib. Manag. 2006, 34, 135-154. [CrossRef]

68. Perrigot, R.; Barros, C.P. Technical efficiency of French retailers. J. Retail. Consum. Serv. 2008, 15, $296-305$. [CrossRef]

69. Yu, W.; Ramanathan, R. An assessment of operational efficiency of retail firms in China. J. Retail. Consum. Serv. 2009, 16, 109-122. [CrossRef]

70. Ozbugday, F.C.; Tirgil, A.; Kose, E.G. Efficiency changes in long-term care in OECD countries: A non-parametric Malmquist Index approach. Socio-Econ. Plan. Sci.. in press. [CrossRef]

71. Liu, B.L.; Li, Q.B. The dynamic analysis of China's city TFP:1990-2006-based on the Malmquist index and DEA model. Nankai Econ. Stud. 2009, 3, 139-152. (In Chinese)

72. Shan, C.X. The R \& D Performance evaluation of high-tech industry based on DEA-Malmquist Index. Method Stat. Decis. 2011, 2, 70-74. (In Chinese)

73. Minbaeva, D.; Pedersen, T.; Björkman, I.; Fey, C.F.; Park, H.J. MNC knowledge transfer, subsidiary absorptive capacity, and HRM. J. Int. Bus. Stud. 2003, 34, 586-599. [CrossRef]

74. Liao, S.-H.; Fei, W.-C.; Chen, C.-C. Knowledge sharing, absorptive capacity, and innovation capability: an empirical study of Taiwan's knowledge-intensive industries. J. Inf. Sci. 2007, 33, 340-359. [CrossRef]

75. Vomberg, A.; Homburg, C.; Bornemann, T. Talented people and strong brands: The contribution of human capital and brand equity to firm value. Strateg. Manag. J. 2015, 36, 2122-2131. [CrossRef]

76. Uotila, J.; Maula, M.; Keil, T.; Zahra, S.A. Exploration, exploitation, and financial performance: analysis of S\&P 500 corporations. Strateg. Manag. J. 2009, 30, 221-231.

(C) 2020 by the authors. Licensee MDPI, Basel, Switzerland. This article is an open access article distributed under the terms and conditions of the Creative Commons Attribution (CC BY) license (http://creativecommons.org/licenses/by/4.0/). 